Twentieth World Congress of Philosophy: Philosophy Educating Humanity,

Section: "American Philosophy"

Boston, 1998, August 15, 14-15:50

\title{
A PLEA FOR A PEIRCEAN TURN IN ANALYTIC PHILOSOPHY
}

\author{
Jaime NUBIOLA* \\ Universidad de Navarra \\ e-mail: jnubiola@ unav.es
}

\author{
"Most people have never heard of him, \\ but they will" \\ W. Percy, "The Divided Creature", 80
}

Criticisms of analytic philosophy have increased in intensity in the last decade, denouncing specifically its closing in on itself, resulting in barrenness and ignorance of real human problems. It is not only the genius loci, nor the echoes of his Sesquicentennial Congress held here in Boston in September, 1989, but within the solemn framework of a World Congress of Philosophy on the threshold of a new century, I wish to propose the study of Charles Sanders Peirce's thought as a fruitful way - there may be others - of renewing the analytic tradition and obviating those criticisms. On the one hand, not only can some of the main roots of analytic philosophy be traced back to Peirce, but the recent resurgence of pragmatism (Bernstein, 1992) can also be regarded as a pragmatist renovation of analytic philosophy. On the other hand, Peirce's thought offers suggestions for tackling some of the most stubborn problems in contemporary philosophy, and in particular he may help us to shoulder once again the philosophical responsibility which has been largely abdicated by much of 20th century philosophy (Debrock, 1992: 1).

In order to show this, my paper is divided in four sections: 1) A brief description of the decline of analytic philosophy; 2) the return of the history of philosophy as a key to its recovery; 3) Charles S. Peirce's relevance, and finally, 4) Peirce and analytic philosophy.

\section{The decline of analytic philosophy}

When Wolfgang Spohn became the managing editor of the new Erkenntnis he referred to its first eight volumes as "a historically singular document, signaling a new era in philosophy with great enthusiasm and optimism" (Spohn, 1990:1). But sixty years after the founding of Erkenntnis it is really difficult to be so enthusiastic about analytic philosophy when one notices the decline of logical empiricism, the bewildering specialization within philosophical inquiry, and contemporary disorientation and eclecticism in philosophy. These trends can be seen as the price of pluralism, as Spohn thought, but also as the derailment of analytic philosophy.

\footnotetext{
* I thank Guy Debrock and Moris Polanco for their suggestions, and to Ruth Breeze for her help with the English version.
} 
According to the standard view analytic philosophy in the hands of European émigrés took over the departments of Philosophy in the American universities in the fifties, becoming the dominant philosophy of the sixties and seventies. The striking fact —as Rorty vigorously pointed out - was that that philosophy which had promised to solve all the genuine philosophical problems arising from scientific activity, thirty years later, it was defined neither by a set of problems systematically studied, nor by some common methods of dealing with them, but only by a mere style or argumentative ability (Rorty, 1982: 211-230). The increasing diversity of issues enabled Rorty to assert that "'Philosophy' in the narrow and professional sense is just whatever we philosophy professors do" (1982: 220).

This situation springs from the failure of the foundationalist project of scientific philosophy, which left as its legacy an aggressive cultural relativism which has pervaded academic philosophy until today. But this is not the only possible reading of the recent history of philosophy. It is also possible to identify in the analytic philosophy of the last decade the beginning of a renewal. Although analytic philosophy claimed to be a piecemeal philosophy, its 'motor' —as Putnam (1983: 303) described — was logical positivism. With the shipwreck of the foundationalist program, analytic philosophy began to lose shape as a tendency. What current analytic philosophers are trying to do is not to save the wreckage of foundationalism, but to reach an understanding of the history of its failure and of the nature of philosophical reflection itself. Philosophy might then be understood as being very similar to art, literature and history (Wittgenstein, 1980: 70), and along these lines it might be possible to close the gap between philosophy as an academic discipline and the deepest aspirations of men and women to know and to live a 'good life'.

\section{The return of the history of philosophy as a key to its recovery}

The overwhelming dominance of the analytic tradition in the Anglo-American world in the last forty years has resulted in neglect of the study of history of thought. As Hilary Putnam wrote, "The long dominance of the idea that 'philosophy is one thing and history of philosophy is another' is now visibly coming to an end" (Putnam, 1997: 200). In some sense, Putnam's own intellectual biography can be understood as an iterated reflection on analytic tradition overcoming its scientism, its "refusal to hear other sorts of philosophy" (Putnam, 1997: 202), and trying to link the problems of philosophers with the problems of men and women, because "it is part of the task of a responsible philosophy to bring out the connection" (Harlan, 1992: 22).

The kantian dualism between two concepts of philosophy, Schulbegriff and Weltbegriff, has probably reached its paroxysm in current Anglo-American Universities, in which Nietzsche, Derrida and other continental philosophers have been exiled to the departments of literature and the history of philosophy has been generally downgraded in philosophy departments. In this sense, the high tradition of analytic philosophy - which traces its roots back to the seminal writings of Frege, Russell and the Vienna Circle - can be understood as the fullest realization of the aspiration of philosophy in its Schulbegriff (Conant, 1990: xxvi). The only alternative to 'metaphysical realism', i. e., to scientism, is not some form of skepticism à la Rorty. Putnam's attempt to rediscover American pragmatist tradition is really attractive: both concepts of philosophy are complementary aspects of a single field of activity. Philosophical enterprise can achieve full fruition when it is pursued under the aspect of each. The analytic tradition might recover its position of leadership in philosophy if it openly rejects "any form of metaphilosophical dualism that takes twin aspirations of rigor and human relevance as the hallmarks of two distinct and incommensurable kinds of philosophical activity" (Conant, 1990: xxxii).

A key source for this 'flashback' process, for this retrieval of 'old good philosophy', is the discovery of a continuous tradition within American thought, which has its beginnings in the debates at Harvard between Royce and James, in the work of Peirce and Dewey, and in the teaching of Lewis (Putnam, 1990: 267), and which is flourishing today. American pragmatism has commonly been seen by European philosophers as something parochial and outside the mainstream of philosophy. Pragmatism is often understood as an 'American way' of dealing with knowledge and truth, but as something alien to the general discussion. As Rorty noted, although philosophers in Europe study Quine and Davidson, "they tend to shrug off the suggestion that these contemporary philosophers share their basic outlook with American philosophers who wrote prior to the so-called linguistic turn" (Rorty, 1990: 1). It becomes more and more apparent that there has been a continuous development of thought from Peirce to Quine, Sellars, Putnam and so on, and that this tradition of thought —as Bernstein suggested - "not only 
challenges the characteristic Cartesian appeal to foundations, but adumbrates an alternative understanding of scientific knowledge without such foundations" (Bernstein, 1983: 71-72).

\section{Charles S. Peirce's relevance}

The figure of Charles S. Peirce has an ever-increasing relevance in very different areas of knowledge (Fisch, 1980): in astronomy, metrology, geodesy, mathematics, logic, philosophy, theory and history of science, semiotics, linguistics, econometrics, and psychology. In all these fields Peirce has been considered a pioneer, a forerunner or even a 'father' or 'founder' (of semiotics, of pragmatism). It is very common to find general evaluations like Russell's "beyond doubt ... he was one of the most original minds of the later nineteenth century, and certainly the greatest American thinker ever" (Russell, 1959: 276) or Umberto Eco's "Peirce was ... the greatest American philosopher of the turn of the century and beyond doubt one the greatest thinkers of his time" (Eco, 1989: x-xi). Even among academic philosophers it has become a commonplace to say that Peirce is the most original philosophical mind that the United States has yet produced (Nagel, 1982: 303) and his seminal role in a wide range of philosophical problems has been alluded to by many philosophers: Popper described Peirce as "one of the greatest philosophers of all times" (Popper, 1972: 212) and Putnam called him "a towering giant among American philosophers" (Putnam, 1990: 252).

Factors which have increased the growing interest in Peirce's thought are his personal participation in the scientific community of his time, his valuable contribution to the logic of relatives, and his sound knowledge of the philosophy of Kant as well as of the Scholastic tradition, in particular Duns Scotus. For these reasons - and owing to his deep original and creative mind - it is possible to find in Peircean thought a way to broaden the analytic mind. At the very root of American analytic philosophy, Peirce can provide a deeper perspective and make possible a renewal of analytic philosophy where human concerns will have a central importance. But also, since Peirce's semiotic took its origins from Scholastic philosophy (Beuchot, 1991; Deely, 1995), it is possible to understand his framework as a renovation of that tradition which has had a central role in Western philosophy.

The main difficulty in the study of Peirce is probably the aforementioned air of provincialism that still hovers around pragmatism. A second difficulty of no less importance is that the interpretation of Peirce's thought has for years provoked a wide disagreement amongst Peirce scholars, in part due to the fragmentary and chaotic presentation of his work in the Collected Papers, and in part due to his going against the grain. The fact is that Peirce is not a philosopher easy to classify: some considered him a systematic thinker, but with four successive systems (Murphey, 1961); others see him as a contradictory thinker (Goudge, 1950), or a speculative metaphysician of an idealist type (Esposito, 1980). But in more recent years a deeper understanding of the architectonic nature of his thought and of his whole evolution from his early writings in 1865 until his death in 1914 has been gaining general acceptance (Hausman, 1993: xiv-xv; Houser and Kloesel, 1992: xxix). In the last decade all Peirce's scholars have clearly acknowledged the basic coherence and undeniable systematization of Peirce's thought (Santaella-Braga, 1993: 401).

Following Hookway to some extent (1985: 1-3), I think that the most accurate understanding of Peirce is to see him as a traditional and systematic philosopher, but one dealing with the modern problems of science, truth and knowledge from a very valuable personal experience as a logician and an experimental researcher in the bosom of an international community of scientists and thinkers.

\section{Peirce and analytic philosophy}

In recent years Alasdair MacIntyre has provided good arguments in defense of cooperative work in philosophy, ethics and the social sciences. The scientific exercise of reason requires learning and the flourishing of intellectual and ethical virtues, and this can only take place in the context of research communities. A century ago Peirce propounded this notion of a community of inquirers, so essential to scientific rationality (Peirce, 1931-58, 5.311). It is well known that this is one of the main themes in the "transcendental pragmatics" of Karl-Otto Apel, whose interpretation establishes that Peirce's thought is the milestone in the semiotic transformation of transcendental philosophy into analytic philosophy. 
Most of the hallmarks of analytic philosophy are already present in Peirce. Many of the issues and insights that have emerged in recent philosophy of science, language, and action were not only anticipated by Peirce, but also explored by him with depth and originality. In recent decades his originality has been recognized, as has his almost uncanny anticipation of those problems and issues now taken to be at the heart of philosophy (Bernstein, 1981: xxi). The best approach to Peirce seems to be to assume that he sought something similar to the analytic philosophy of language: his underlying motivation and basic ideas have much in common with it (Hookway, 1985: 141) and Peirce -according to Wright (1993: 41) — could even be counted with Frege, Russell and Wittgenstein, as one of the founding fathers of analytic philosophy.

Thirty years ago, in his first published paper, Rorty claimed that Peirce's thought envisaged, and repudiated in advance, the stages in the development of empiricism which logical positivism represented, arriving at a group of insights and a philosophical mood much like those of Philosophical Investigations (Rorty, 1961: 197-198). But in fact British analytic philosophy was ignorant of Peirce, with the exception of F. P. Ramsey and the sketchy account of Peirce in The Meaning of Meaning (1923). The proximity between Wittgenstein and Peirce has been well studied (Boghossian and Drewniak, 1995; Nubiola, 1996), but the study of Peirce's thought can shed great light on the way to integrate better the variety of piecemeal issues within the framework of philosophy. As Hookway suggests, in Peirce's work there is not just the parallel development of themes found in the work of Frege, Russell or Wittgenstein, but also the framework for an integrated theory of culture (Hookway, 1985: 120). A Peircean approach to philosophy offers both deep involvement in currently highly specialized and technical philosophical discussion, and the resources to participate in the general conversation of mankind. It maintains in stable equilibrium both kantian concepts of philosophy, and is thus probably the best way in which analytic philosophy can be fully renovated and be opened to show - in Putnam's expression- a more human face.

One hundred years ago, in February and March of 1898, Charles S. Peirce gave a course of eight lectures at 168 Brattle Street, Cambridge, on Reasoning and the Logic of Things. In the introduction to the

first publication of that course only six years ago, K. L. Ketner and H. Putnam wrote that "this set of lectures offers to both expert and layperson the most convenient and complete means for gaining access to those ideas and insights in Peirce's philosophy which are specially relevant to a number of contemporary issues" (Peirce, 1992: 3). I want to finish my defense of the study of Peirce as a royal road to renovating analytic philosophy with a short quotation from the first of those lectures: "In philosophy ... the investigator who does not stand aloof from all intent to make practical applications, will not only obstruct the advance of pure science, but what is infinitely worse, he will endangers his own moral integrity and that of his readers" (Peirce, 1992: 107). And as you know, and the history of philosophy provides a lot of evidence to this effect, the "lack of intellectual integrity is apt, in the long run and on the whole, to impede inquiry" (Haack, 1996: 59).

\section{BIBLIOGRAPHIC REFERENCES}

R. J. Bernstein, "Introduction", in K. Apel, Charles S. Peirce. From Pragmatism to Pragmaticism, University of Massachusetts Press, Amherst, MA, 1981, xix-xxvi.

R. J. Bernstein, Beyond Objectivism and Relativism: Science, Hermeneutics, and Praxis, Blackwell, Oxford, 1983.

R. J. Bernstein, "The Resurgence of Pragmatism", Social Research 59, (1992), 813-840.

M. Beuchot, "La filosofía escolástica en los orígenes de la semiótica de Peirce", Analogía 2 (1991), 155-166.

P. G. Boghossian y E. Drewniak, "Wittgenstein and Peirce on Meaning", Diálogos 30 (1995), 173-188.

J. Conant, " Introduction" in H. Putnam, Realism with a Human Face, Harvard University Press, Cambridge, MA, 1990, xv-lxxiv.

G. Debrock, "Peirce, a Philosopher for the 21st Century. Introduction", Transactions of the Ch. S. Peirce Society 28 (1992), 1-18. 
J. Deely, "Common Sources for the Semiotic of Charles Peirce and John Poinsot", Review of Metaphysics 48 (1995), 539-566.

U. Eco, "Introduction", in C. K. Ogden and I. A. Richards, The Meaning of Meaning, 4th ed., Harcourt, San Diego, CA, 1989, v-xi.

J. Esposito, Evolutionary Metaphysics. Ohio University Press, Athens, OH, 1980.

J. Harlan, "Interview with Hilary Putnam", The Harvard Review of Philosophy, Spring (1992), 20-24.

M. Fisch, "The Range of Peirce's Relevance", The Monist 63 (1980), 269-276; 64,123-141.

T. Goudge, The Thought of C. S. Peirce. University of Toronto Press, Toronto, 1950.

S. Haack: "Concern for Truth: What it Means, Why it Matters", in P. R. Gross et al, eds., The Flight from Science and Reason, Annals of the New York Academy of Sciences 775 (1996), 57-63.

C. Hausman, Charles S. Peirce's Evolutionary Philosophy, Cambridge University Press, New York, 1993

C. Hookway, Peirce, Routledge \& Kegan Paul, London, 1985.

N. Houser and C. Kloesel, eds., The Essential Peirce. Selected Philosophical Writings, Indiana University Press, Bloomington, IN, 1992.

M. G. Murphey, The Development of Peirce's Philosophy, Harvard University Press, Cambridge, MA, 1961.

E. Nagel, "Peirce's Place in Philosophy", Historia Mathematica 9 (1982) 302-310.

J. Nubiola, "Scholarship on the Relations between Ludwig Wittgenstein and Charles S. Peirce", in I. Angelelli y M. Cerezo, eds., Studies on the History of Logic. Proceedings of the III Symposium on the History of Logic, Walter de Gruyter, Berlin, 1996, 281-294

C. K. Ogden and I. A. Richards, The Meaning of Meaning, Routledge \& Kegan Paul, London, 1923.

C. S. Peirce, Collected Papers, vols. 1-8, C. Hartshorne, P. Weiss and A. W. Burks, eds., Harvard University Press, Cambridge, MA, 1931-58.

C. S. Peirce, Reasoning and the Logic of Things. The Cambridge Conferences Lectures of 1898, K. L. Ketner, ed., Harvard University Press, Cambridge, MA, 1992.

W. Percy, "The Divided Creature", The Wilson Quarterly 13 (1989), 77-87.

K. R. Popper, Objective Knowledge: An Evolutionary Approach, Clarendon Press, Oxford, 1972.

H. Putnam, Realism and Reason, Philosophical Papers III, Cambridge University Press, Cambridge,1983.

H. Putnam, Realism with a Human Face, Harvard University Press, Cambridge, MA, 1990.

H. Putnam, "A Half Century of Philosophy, Viewed From Within", Daedalus 126 (1997), 175-208.

R. Rorty, "Pragmatism, Categories, and Language", Philosophical Review 70 (1961), 197-223.

R. Rorty, Consequences of Pragmatism (Essays: 1972-1980), University of Minnesota Press, Minneapolis, 1982.

R. Rorty, "Pragmatism as Anti-Representationalism", in J. P. Murphy, Pragmatism from Peirce to Davidson, Westview, Boulder, CO, 1990, 1-6. 
B. Russell, Wisdom of the West, Doubleday, Garden City, NY, 1959.

L. Santaella-Braga, "Difficulties and Strategies in Applying Peirce's Semiotics", Semiotica 97 (1993), 401410.

W. Spohn, "Editorial Note", Erkenntnis 33 (1990) 1-4.

L. Wittgenstein, Culture and Value, G. H. von Wright, ed., Blackwell, Oxford, 1980.

G. H. von Wright, The Tree of Knowledge and Other Essays, Brill, Leiden, 1993. 